$\underline{\text { www.cjes.eu }}$

\title{
Professional commitment: Its effect on kindergarten teachers' organizational citizenship behavior
}

Gunarti Dwi Lestari a *, Universitas Negeri Surabaya, Department of Education, Surabaya, Indonesia, https://orcid.org/0000-0003-4688-844X

Umi Anugerah Izzati b, Universitas Negeri Surabaya, Department of Education, Surabaya, Indonesia, https://orcid.org/0000-0001-5780-514X

Kartika Rinakit Adhe ', Universitas Negeri Surabaya, Department of Education, Surabaya, Indonesia, https://orcid.org/0000-0002-3366-7026

Dian Eka Indriani ${ }^{\text {d }}$, STKIP PGRI Bangkalan, Department of Education, Madura, Indonesia, https://orcid.org/0000$\underline{0002-5433-6656}$

\section{Suggested Citation:}

Lestari, G. D., Izzati, U. A., Adhe, K. R., \& Indriani, D. E., (2021). Professional commitment: Its effect on kindergarten teachers' organizational citizenship behavior. Cypriot Journal of Educational Science. 16(4), $2037-2048$. https://doi.org/10.18844/cjes.v16i4.6072

Received from March 21, 2021; revised from June 15, 2021; accepted from August 23, 2021.

(C)2021 Birlesik Dunya Yenilik Arastirma ve Yayincilik Merkezi. All rights reserved.

\section{Abstract}

Organizational Citizenship Behavior (OCB) is one of the keys to the success of an organization. This current research aims to evaluate the effect of Professional Commitment on Kindergarten teachers' OCB. This quantitative research applies a crosssectional survey design with an explanatory research type, with 145 Kindergarten teachers as the research subjects. The results show that Professional Commitment significantly affects OCB by $70.6 \%$. In addition, teachers with higher Professional Commitment possess higher OCB in carrying out their professional duties. The results also show that the dimensions of Affective Professional commitment, Normative Professional commitment, and Continuance Professional commitment significantly affect the OCB of Kindergarten teachers.

Keywords: Professional Commitment, Organizational Citizenship Behavior, kindergarten teachers 


\section{Introduction}

\subsection{Conceptual or Theoretical Framework}

Schools as an organization must be well managed to make the educational programs run effectively and efficiently (Fiftyana \& Sawitri, 2018). Each level of education - from early childhood education to high schools and colleges - has the same goal: preparing human resources that can compete globally. Human resources in schools are the determinant factors of success in achieving the schools' goals. One of the human resources that play an essential role is teachers (Putranti \& Kurniadi, 2013).

Teachers, including kindergarten teachers, play a vital part in improving the schools' quality of education (Rosyati et al., 2020). Kindergarten teachers must possess great affection for children and have a good, attractive, and energetic personality. Besides, they must master the educational sciences, child development psychology, and basic concepts of child learning. The facts imply that becoming a kindergarten teacher is not easy, even the most difficult one (Putranti \& Kurniadi, 2013).

Kindergarten teachers are faced with a high number of demands, which require them to possess a quality of behavior that is beyond their job description (Karnati \& Widihartati, 2018). Such kind of behavior is recognized as Organizational Citizenship Behavior (OCB). Such kind of behavior is recognized as Organizational Citizenship Behavior (OCB). Some research had shown that teachers with higher OCB tend to be more loyal and devoted to their schools (Nugroho et al., 2016). In addition, Rahman (2014) explained that high OCB significantly contributes to the attainment of the schools' goals.

According to Organ et al., (2006), OCB contains five aspects: 1) Altruism, reducing the workload of coworkers; 2) Courtesy, helping coworkers prevent the occurrence of work-related problems; 3 ) Sportsmanship, respecting colleagues when an unexpected situation occur at work; 4) Civic Virtue, being involved in organizational activities and having concern for the sustainability of the organization; and 5) Conscientiousness, conducting activities that generate benefits for the organization.

Employees with OCB generally possess the following characteristics of behavior: 1) voluntarily doing jobs beyond their responsibility, 2) spontaneously doing their works, without waiting to be told or advised by others to do so, either by superiors or co-workers, 3) doing works that benefit the organization and help the organization to survive, 4) doing jobs that are difficult to assess by any performance evaluation, because the jobs are not in their job descriptions (LePine et al., 2002; Sahrah, 2017).

Based on interviews with teachers and observations in one of the Kindergartens in Surabaya, Indonesia, it was found that some teachers displayed non-spontaneous working behavior and tended to be passive. For example, some teachers were reluctant to replace other teachers who were sick. Some teachers were also unwilling to introduce new teachers to their jobs and to other colleagues. It happened because they thought that the jobs were not their responsibility. Besides, they also thought that developing the school to a more advanced level is the responsibility of the principal, not theirs.

The phenomenon of how professional commitment affects OCB is interesting to study because, to the best of the researchers' knowledge, there has been no research that discusses the influence of Professional Commitment to OCB among Kindergarten teachers. Some previous studies discussing professional commitment and $O C B$ emphasized more on the subjects of employees or nurses. Research on the effect of professional commitment on OCB among kindergarten teachers needs to be done. It is because kindergarten teachers often have to do jobs beyond their job descriptions, such as replacing absent teachers. In this case a committed teacher is needed because a teacher's physical presence in the classroom at a kindergarten school is a must. In addition, even though it is not in their job 
descriptions, teachers sometimes must wash the children after urinating or defecating or mop the floor. All of this requires a higher level of Professional Commitment.

\subsection{Related Research}

Many scholars have defined what OCB is. Newstrom (2007) argued that OCB is an action that goes beyond the job description and is determined independently, increasing the organizational success. According to Organ et al., (2006), OCB is a behavior that is consciously and voluntarily performed but is not straightforwardly associated with the reward system. Robbins and Judge (2017) added that OCB is a behavior that is beyond formal job obligation but will increase the effectiveness of an organization. Based on the definitions above, it can be inferred that OCB is a voluntary behavior performed by individuals in carrying out their professional duties and obligations that eventually increases the organization's effectiveness.

Teachers who work in schools need to possess OCB. Ambarwati (2019) revealed the positive impacts of OCB which include increased organizational effectiveness, innovation awareness, and ability to adapt in various organizations. Further, she explained that high OCB contributes significantly to the organizational success (e.g., faster work completion times, lower operating costs, and optimal use of existing resources). OCB optimization can reduce the need to mobilize scarce resources and simplify maintenance functions, thus increasing employee effectiveness and efficiency. In addition, a study by Sulastri et al., (2018) revealed that OCB gives a positive consequence for employees and companies.

Professional Commitment is the relative strength which is identified from one's involvement in a profession. It may include one's belief in and approval of the organizational goals and values, the readiness to work hard for the organization, and the willingness to maintain membership in a profession (Aranya et al., 1981). According to Aryee et al., (1991), professional commitment is the belief or acceptance of various professional goals and values, the inclination to exercise effort for the profession, and the desire to uphold membership in the profession. According to Elias (2006), Professional Commitment is one's individual attachment to his/her profession. Bagraim (2003) explains that Professional Commitment is the belief and acceptance of the values of the profession and the willingness to maintain a position in the profession. Based on the definitions, it can be concluded that Professional Commitment is the belief and acceptance of various goals, objectives, and values of the profession and the willingness to remain in the profession.

Wirawan (2014) explained that several factors might affect OCB, including personality, organizational climate, organizational commitment, transformational leadership, servant leadership, job satisfaction, employee's social responsibility, employee's age, organizational culture, and collectivism. Ozdem (2012) added that Professional Commitment is one of the factors that also affect OCB. In his opinion, Professional Commitment is more effective than Organizational Commitment. This is also in line with Duarte's research (2015), which showed that professional commitment has a substantial association with OCB.

\subsection{Purpose of the Study}

This current research focuses on the variables of Professional Commitment and Organizational Citizenship Behavior (OCB). It is because no study has ever examined the effect of Professional Commitment on OCB among kindergarten teachers. Studies by Somech and Boglera (2002), Boglera and Somech (2004), Özdem (2012), Duarte (2015), Azan et al. (2015), and Arifiani et al., (2020), discussed professional commitment or OCB. However, the studies did not take the research subjects of kindergarten teachers who needed OCB. Duarte (2015), for example, discovered that Professional 
Commitment had a significant relationship to nurses' OCB. Likewise, Azan et al. (2015) revealed that Organizational Commitment and Professional Commitment, simultaneously and partially, had a substantial effect on OCB.

Analyzing the effect of professional commitment on OCB among kindergarten teachers is very important to do because this profession requires high $\mathrm{OCB}$. The results of this current research can also be used as a reference for schools to increase their teachers' Professional Commitment because committed teachers have a robust psychological relationship with their profession. They are willing to be involved in helping the organization achieve the goals and are eager to make a variety of efforts beyond minimum expectations and remain within the organization. Moreover, the results of the research can be used by the government to formulate some policies related to early childhood education and develop early childhood education institutions. In line with the research background, the research hypotheses can be formulated as follows:

H1: Professional Commitment has significant effect on the Organizational Citizenship Behavior (OCB) of Kindergarten Teachers

HO: Professional Commitment has no effect on the Organizational Citizenship Behavior (OCB) of Kindergarten Teachers

\section{Method and Materials}

\subsection{Research Model}

This is quantitative research focusing on numerical data (numbers), which is then analyzed using statistical methods (Azwar, 2017). This research is an explanatory survey research with a cross-sectional approach to explore, analyze and explain the effect of Professional Commitment on the Organizational Citizenship Behavior of Kindergarten teachers. The analysis is applied to predict how the criterion variable will be (i.e., up and down) when two or more predictor variables are manipulated (Gunawan, 2017).

\subsection{Participants}

The research was conducted in 2019 in the city of Surabaya, in East Java, Indonesia. Convenience sampling was applied to select individuals as the research subjects with demographic profile as follow.

Table 1: The profile of the respondents

\begin{tabular}{clcc}
\hline & \multicolumn{1}{c}{ Profile } & Frequency & Percentage \\
\hline \multirow{2}{*}{ Sex } & Male & 12 & 8.2 \\
& Female & 133 & 91.7 \\
& Unmarried & 20 & 13.8 \\
\multirow{3}{*}{ Status pernikahan } & Married & 118 & 81.3 \\
& Widow/Widower & 7 & 4.8 \\
\cline { 2 - 3 } Education & Undergraduate & 135 & 93.1 \\
& Master & 10 & 6.8 \\
& 1-5 years & 24 & 16.5 \\
& 6-10 years & 18 & 12.4 \\
& $11-15$ years & 37 & 25.5 \\
& $16-20$ years & 20 & 13.8 \\
& 21-25 years & 17 & 11.7 \\
\hline
\end{tabular}




\begin{tabular}{cccc}
\hline $26-30$ years & 15 & 10.3 \\
$31-40$ years & & 4 & 2.8 \\
& Total & 145 & $100 \%$ \\
\hline
\end{tabular}

Source: processed data

Based on the information in table 1, there were 145 kindergarten teachers as samples. Based on the data obtained, most of the respondents were women (91.7\%) and married $(81.46 \%)$. In terms of educational background, most respondents (93.1\%) were undergraduate graduates, and only ten people (6.8\%) had master's degrees. Based on the length of service, most of the respondents had a working period of $11-15$ years (37 or $25.5 \%$ ).

\subsection{Data Collection Tools}

The instruments used to collect the data were two scales: a Professional Commitment scale and an Organizational Citizenship Behavior (OCB) scale. The Professional Commitment scale followed Bagraim (2003), while the OCB scale was constructed based on the hypothetical notion suggested by Organ et al. (2006).

The scales were arranged according to the Likert scale containing five answer choices, from 1 (strongly disagree) to 5 (strongly agree). Two professors of Curriculum and Educational Technology, Universitas Negeri Surabaya, had examined and evaluated for the validity and reliability of the arranged scales had been by and had got satisfactory results.

Based on the test result of the Professional Commitment scale to 30 respondents, it was found that the Pearson's $r$ value was between 0.521 and 0.753 and the significance value ( $P$-value) was less than 0.05 . It means that the Professional Commitment items can be said to have got high validity. Meanwhile, the reliability test of the Professional Commitment variable obtained a Cronbach alpha value of 0.880 , more than 0.6. It means that the questionnaire and the statement items on the Professional Commitment variable are reliable.

The test for the OCB scale got Pearson's $r$ value from 0.580 to 0.763 and a significance value (P-Value) less than 0.05 . The result indicates that the statement items forming the OCB variables have got a high validity value. Meanwhile, the Cronbach alpha value was 0.860 (more than 0.6 ), which means that the questionnaire and the statement items on the OCB variables are reliable. Therefore, the two instruments in this study can be applied and distributed to the respondents to collect the data.

\subsection{Data Collection Process}

The data were collected through the following steps: 1) The scales were distributed to the respondents by the Kindergarten School Coordinators, 2) After two weeks, 145 of the 200 scales were returned and collected for analysis by the primary research team, and 3) The scales were tabulated and scored for each statement, totaling 15 statement items on the Professional Commitment scale and ten items on the Organizational Citizenship Behavior scale.

\subsection{Data Analysis}

Based on the respondents' answers on the OCB and Professional Commitment scales, a statistical analysis was carried out following the stages as follows:

1. Normality test. It was to determine whether the data were normally distributed or not. The normality test in this current research used the Kolmogorov-Smirnov one-sample test with a significance level 
of more than $5 \%$ or $p>0.05$. The result showed that the significance value was 0.717 (more than 0.05). Hence, it could be inferred that the regression model residuals were distributed normally.

2. Assumption test. Heteroscedasticity indicates an inequality of variance. A good regression model does not show heteroscedasticity. In this research, the detection of heteroscedasticity was carried out using the Glejser test. If the significance value is more than 0.05 ( $\alpha=5 \%$ ), there is no heteroscedasticity in the regression model.

The result showed that the significance value was 0.133 for Affective Professional, 0.403 for Normative Professional, and 0.984 for Continuance Professional. It means that the values were above 0.05 . Hence, it can be determined that there was no heteroscedasticity in the regression model. In other words, the non-heteroscedasticity assumption had been met.

3. Descriptive statistics. Descriptive statistics are data analysis by calculating each item's mean, standard deviation, and category descriptions (Gunawan, 2017).

4. Hypothesis Testing. The hypothesis testing applied the multiple linear regression analysis to measure the relationship between the variables of Professional Commitment and Organizational Citizenship Behavior of kindergarten teachers. The result of the test determined the determinant coefficient, revealing the effect of Professional Commitment on OCB. In addition, a cross-tabulation on the demographic data of respondents (i.e., gender, marital status, and years of service) was applied to determine the factors that affect Organizational Citizenship Behaviour.

\section{Results}

\section{Descriptive statistics}

The mean and standard deviation of the subjects' answers are explained in each item of the Professional Commitment variables (i.e., Affective Professional commitment (AP), Continuance Professional commitment (CP), and Normative Professional commitment (NP)) and Organizational Citizenship Behavior (OCB).

Table 2. Description of Professional Commitment

\begin{tabular}{ccccc}
\hline Dimension & Item & \multicolumn{2}{c}{ Value } & Std. Deviation \\
\hline \multirow{3}{*}{ AP } & AP1 & 3.88 & 0,983 \\
& AP2 & 3.07 & 3.72 & 1.254 \\
& AP3 & 3.78 & 0.885 \\
& AP4 & 3.74 & & 1.066 \\
& AP5 & 4.16 & & 0,905 \\
NP & NP1 & 4.06 & & 0,938 \\
& NP2 & 2.84 & & 1.319 \\
& NP3 & 4.04 & 3.61 & 0.827 \\
& NP4 & 3.15 & & 1.271 \\
& NP5 & 3.95 & & 0,954 \\
& CP1 & 3.68 & & 0,982 \\
& CP2 & 3.85 & & 1.004 \\
CP & CP3 & 3.28 & 3.62 & 1.200 \\
& CP4 & 3.56 & 1.016 \\
& CP5 & 3.73 & & 1.059 \\
\hline
\end{tabular}




\begin{tabular}{cccc}
\hline Dimension & Item & Value & Std. Deviation \\
\hline Total & & 3.65 & \\
\hline
\end{tabular}

Source: processed data

Table 2 shows that, on average, the respondents' answers on the Professional Commitment variables were 3.65, approaching a scale of 4 (agree) on a Likert scale of 1-5. It indicates that the respondents well perceived Professional Commitment. The respondents' highest perception of Professional Commitment was on the dimension of Affective Professional Commitment (3.72), while the lowest perceived Professional Commitment was on the dimension of Normative Professional commitment (3.61). The lowest standard deviation was on the dimension of Normative Professional commitment 3 (NP3) of 0.827.

Table 3. Description of Organizational Citizenship Behavior

\begin{tabular}{ccc}
\hline \hline Item & Value & Std. Deviation \\
\hline OCB 1 & 3.93 & 0,983 \\
OCB 2 & 3.48 & 0,969 \\
OCB 3 & 2.95 & 1.149 \\
OCB 4 & 3.62 & 1.030 \\
OCB 5 & 2.79 & 1.296 \\
OCB 6 & 4.06 & 1.027 \\
OCB 7 & 3.98 & 0,960 \\
OCB 8 & 4.02 & 1.029 \\
OCB 9 & 2.80 & 1.353 \\
OCB 10 & 2.83 & 1.302 \\
OCB & 3.44 & \\
\hline \hline
\end{tabular}

Source: processed data

As described in table 3, the highest respondents' perception of the Organizational Citizenship Behavior was on OCB6 (4.06), while the lowest perception was on OCB5 (2.79). The lowest standard deviation was on OCB7 (0.960), indicating that the respondents' perception of this item was more homogeneous than their perception of other items. In total, the average value of the OCB items was 3.44, indicating that the respondents' Organizational Citizenship Behavior was quite good.

\section{Hypothesis testing}

The result of the t-test analysis showed that Professional Commitment affected OCB by 0.442 , with a significance value of 0.659 . More specifically, the dimension of AP showed a t-count of 6.111 ; the NP showed a t-count of 5.178, with a significance value of 0.000 ; and the CP showed a t-count of 2.674, with a significance value of 0.008 , less than $0.05(\alpha=5 \%)$. Therefore, it can be concluded that the variable of Professional Commitment has a significant relationship with OCB: 
Table 4. The relationship between Professional Commitment and OCB of Kindergarten teachers

\begin{tabular}{|c|c|c|c|c|c|}
\hline \multirow{2}{*}{ Model } & \multicolumn{2}{|c|}{ Nonstandard Coefficient } & \multirow{2}{*}{$\begin{array}{c}\text { Standard } \\
\text { Coefficient } \\
\text { Beta }\end{array}$} & \multirow{2}{*}{$\mathbf{T}$} & \multirow{2}{*}{ Sig. } \\
\hline & B & Std. Error & & & \\
\hline 1 (Constant) & 0,085 & 0,193 & & .442 & 0,659 \\
\hline Affective professional commitment & 0,418 & 0,068 & 0,402 & 6.111 & .000 \\
\hline Normative professional commitment & 0,354 & 0,068 & 0,388 & 5.178 & .000 \\
\hline Continuance professional commitment & 0,144 & 0,054 & .160 & 2.674 & 0,008 \\
\hline
\end{tabular}

Note. Dependent Variable: Organizational Citizenship Behavior (OCB)

As described in Table 4, the regression equation obtained is $\mathrm{OCB}=0.085+0.418 \mathrm{AP}+0.354 \mathrm{NP}+$ $0.144 C P$. The determination coefficient indicates the data variation in the dependent variable $(Y)$, which can be explained by the variation of the data in the independent variable $(X)$. The following are the values of the Coefficient of Determination generated in the regression model:

Table 5. Coefficient of Determination

\begin{tabular}{ccccc}
\hline Model & $\mathbf{R}$ & $\mathbf{R}$ Square & Customized R Square & Std. Estimation Error \\
\hline 1 & $0,840 a$ & 706 & 0,700 & 0,35412 \\
\hline Note: & a. Predictor: (Constant), continuance professional, affective professional, normative professional
\end{tabular}

b. Dependent Variable: Organizational Citizenship Behavior (OCB)

Table 5 shows that the value of the determination coefficient is 0.706 . It indicates that $70.6 \%$ of the variation of OCB data can be explained by the dimensions of the Professional Commitment variables: i.e., Affective Professional commitment, Normative Professional commitment, and Continuance Professional commitment. In other words, it can be concluded that the three kinds of commitment, as a whole, affect the OCB significantly by $70.6 \%$.

\section{Cross Tabulation Data}

The cross-tabulation result indicates that most female teachers (70 out of 145 teachers) possessed higher Professional Commitment. Furthermore, 46 female teachers showed higher OCB behavior. Therefore, it can be inferred that female teachers tend to have higher Professional Commitment and higher OCB behavior than male teachers.

The cross-tabulation result also shows that most married teachers had higher Professional Commitment ( 63 people) and higher OCB ( 42 people). The data confirm that married teachers tended to possess higher Professional Commitment and OCB than their unmarried peers. Therefore, it can be concluded that the longer the kindergarten teachers' years of service, the higher their Professional Commitment and OCB.

\section{Discussion}

This current research is to evaluate the effect of Professional Commitment on the OCB of kindergarten teachers. Besides, this study is to identify the factors that affect OCB by cross tabulating the respondents' demographic data (i.e., gender, marital status, and years of service).

Based on the research results, the variable of Professional Commitment significantly affects the teachers' OCB. The result is in line with the research by Duarte (2015) and Azan et al. (2015), showing that Professional Commitment is closely related to the OCB of nurses. 
Affective Professional Commitment (AP), the involvement or attachment to the profession (Meyer et al., 1993), has a significant effect on the teachers' OCB. Therefore, it can be inferred that the teachers' high level of emotional attachment significantly influences their efforts in educating the students.

Furthermore, Normative Professional commitment (NP), which is a commitment based on professional obligations, has a significant effect on OCB. Meyer et al., (1993) explained that the commitment can develop due to effective professional socialization or due to a willingness to become a member of a specific profession. Thus, it can be determined that those with a higher sense of professional obligation can take an extra part in teaching the students, as a form of their responsibility.

The Continuance Professional commitment (CP), which denotes a commitment based on individual recognition of the costs related to parting with the profession (Meyer et al., 1993), significantly affects the teachers' OCB. The result indicates that Kindergarten teachers with a stronger desire to continue working always try to improve their abilities, provide the best for their students, and improve their professional quality.

The results designate three dimensions of commitment: Affective Professional commitment, Continuance Professional commitment, and Normative Professional commitment. The three dimensions, all in all, affect the OCB significantly (70.6\%), among which the Affective Professional commitment has got the most significant effect on OCB. Other minor factors (29.4\%) - i.e., personality, job satisfaction, motivation, individual trust in coworkers, leadership, and group characteristics - that may influence the OCB of kindergarten teachers were not studied because they are not the focus of this current research.

The effect of the three dimensions on the kindergarten teachers' OCB takes some forms, i.e., increased emotional attachment to their profession, feeling proud of their work, and being more involved in all activities related to their works. Moreover, those who have higher Professional Commitment show some positive behavior, e.g., willingness to devote themselves to their profession and fulfill the professional obligations.

The results of this current research also show that female teachers, those with longer terms of service, and those with families, tend to have higher Professional Commitment and OCB in carrying out their duties. In the school environment, teachers' Professional Commitment is governed by their sense of involvement, which in turn determines the amount of effort to improve the students' learning and well-being (Firestone \& Pennell, 1993). Highly committed professional teachers are required to get proficiency in new subjects and areas that support their works, improve their ability to address specific students' needs, and develop their classroom performance.

Committed teachers possess a solid psychological attachment with their profession, want to be involved in helping the organization attain its goals and objectives, and want to go beyond the minimum expectations and remain within the organization (Somech \& Bogler, 2002). Teacher empowerment, status, and self-efficiency are critical in predicting overall organizational outcomes. Therefore, this needs to be understood by school stakeholders who seek to increase teachers' professional and organizational commitment and increase the teachers' OCB (VanDyne et al., 1994).

Individuals with higher Professional Commitment retain positive characters, such as high trust and acceptance of the professional goals, desire to give the best to their profession, and strong desire to maintain membership (Pandey et al., 2008; Bogler \& Somech, 2004). Furthermore, committed kindergarten teachers need to be continuously encouraged to develop the excellence of education and increase the number of students. 
Therefore, school organizations need to build working conditions to make teachers have high competence, experience, and self-esteem. Principals also need to be aware that teachers' feelings, perceptions of the school, and desire to achieve professional growth opportunities are beneficial to the organization (Somech \& Bogler, 2002; Cohen \& Liu, 2011).

However, this study has got several drawbacks, namely the population range that needs to be expanded. In addition, this study does not concern with other variables that possibly affect OCB.

\section{Conclusion}

From the results of the hypothesis testing conducted, it comes to conclusions that Professional Commitment significantly affects the kindergarten teachers' OCB. It is also inferred that Affective Professional commitment, Continuance Professional commitment, and Normative Professional commitment significantly affect OCB. Meanwhile, other factors (i.e., personality, job satisfaction, motivation, level of individual trust in coworkers, leadership, and group characteristics) have a lower effect on OCB (29.4\%).

The results prove that Professional Commitment positively affects OCB. It means that the higher the Professional Commitment, the higher the teacher's OCB in the workplace; conversely, the lower the teachers' Professional Commitment, the lower their motivation to demonstrate OCB in the workplace. In addition, it was also found that teacher demographic data play a role in OCB, particularly gender, marital status, and work experience. Married female teachers and senior teachers have a higher Professional Commitment and higher OCB.

\section{Recommendation}

However, this study has several limitations. The number of subjects is limited and only applied to kindergarten teachers in East Java province. In addition, this study does not pay attention to other variables that possibly affect OCB. Therefore, further research may enlarge the number of the subjects and expand the research area and consider other variables that possibly affect OCB, such as personality factors, job satisfaction, motivation, and the level of individual trust in coworkers, leadership, and group characteristics.

\section{Acknowledgments}

The authors would like to appreciate the rector of Universitas Negeri Surabaya who has given support, and all parties who has helped implementing and completing this study. We also thank the school and the respondents for all the positive responses.

\section{References}

Ambarwati, A. (2019). Hubungan Karakteristik Individu, Budaya Organisasi, Dan Organization Citizenship Behavior Dengan Kinerja Organisasi. Journal of Applied Business Administration, 3(1), 111-118. https://doi.org/10.30871/jaba.v3i1.1289

Aranya, N., Pollock, J., \& Amernic, J. (1981). An examination of professional commitment in public accounting. Accounting, Organizations and Society, 6(4), 271-280. https://doi.org/10.1016/0361-3682(81)90007-6

Aryee, S., Wyatt, T., \& Min, M. K. (1991). Antecedents of organizational commitment and turnover intentions among professional accountants in different employment settings in singapore. Journal of Social Psychology, 
Lestari, G. D., Izzati, U. A., Adhe, K. R., \& Indriani, D. E., (2021). Professional commitment: Its effect on kindergarten teachers' organizational citizenship behavior. Cypriot Journal of Educational Science. 16(4), 2037-2048. https://doi.org/10.18844/cjes.v16i4.6072

131(4), 545-556. https://doi.org/10.1080/00224545.1991.9713884

Azan, P. G., Suryatiningsih, D., \& Nuryanti. (2015). Pengaruh organizational commitment dan professional commitment terhadap organizational citizenship behavior karyawan PT. Telkomsel Pekanbaru. Jom FEKON, 2(2), 1-11. https://jom.unri.ac.id/index.php/JOMFEKON/article/view/11500

Azwar, S. (2017). Metodology penelitian psikologi. Yogyakarta: Pustaka Pelajar. (II). Pustaka Pelajar.

Bagraim, J. J. (2003). The dimensionality of professional commitment. SA Journal of Industrial Psychology, 29(2), 6-9. https://doi.org/10.4102/sajip.v29i2.104

Bogler, R., \& Somech, A. (2004). Influence of teacher empowerment on teachers' organizational commitment, professional commitment and organizational citizenship behavior in schools. Teaching and Teacher Education, 20(3), 277-289. https://doi.org/10.1016/J.TATE.2004.02.003

Brito Duarte, M. (2015). Organisational and professional commitments: The influence in nurses' organisational citizenship behaviours. Tékhne, 13(1), 2-11. https://doi.org/10.1016/j.tekhne.2015.03.001

Cohen, A., \& Liu, Y. (2011). Relationships between in-role performance and individual values, commitment, and organizational citizenship behavior among Israeli teachers. International Journal of Psychology, 46(4), 271287. https://doi.org/10.1080/00207594.2010.539613

Davis, K., \& Newstrom, J. W. (1977). Human Behavior At Work: Organizational Behavior. McGraw-Hill/Irwin.

Elias, R. Z. (2006). The impact of professional commitment and anticipatory socialization on accounting students' ethical orientation. Journal of Business Ethics, 68(1), 83-90. https://doi.org/10.1007/s10551-006-9041-5

Fiftyana, \& Sawitri. (2018). Hubungan Antara Kecerdasan Emosional Dengan Organizational Citizenship Behavior (Ocb) Pada Guru Sekolah Dasar (Sd) Negeri Di Kecamatan Banyumanik Kota Semarang. Empati, 7(1), 397405.

Firestone, W. A., \& Pennell, J. R. (1993). Teacher Commitment, Working Conditions, and Differential Incentive Policies. Review of Educational Research, 63(4), 489-525. https://doi.org/10.3102/00346543063004489

Gunawan, I. (2017). Pengantar statistik inferensial (I). Rajawali Pers. http://perpus.jombangkab.go.id/inlislite3/opac/detail-opac?id=15909

Karnati, N., \& Widihartati, S. M. (2018). Pengaruh Pengawasan Dan Penghargaan Terhadap Organization Citizenship Behavior (Ocb) Guru Paud Di Kabupaten Manokwari. IMPROVEMENT: Jurnal Ilmiah Untuk ..., 5(1), 11-21. http://journal.unj.ac.id/unj/index.php/improvement/article/view/11235

Lepine, J. A., Erez, A., \& Johnson, D. E. (2002). The nature and dimensionality of organizational citizenship behavior: a critical review and meta-analysis. The Journal of Applied Psychology, 87(1), 52-65. https://doi.org/10.1037/0021-9010.87.1.52

Meyer, J. P., Allen, N. J., \& Smith, C. A. (1993). Commitment to Organizations and Occupations: Extension and Test of a Three-Component Conceptualization. Journal of Applied Psychology, 78(4), 538-551. https://doi.org/10.1037/0021-9010.78.4.538

Nugroho, D. S., Sutjipto, S., \& Matin, M. (2017). Hubungan antara Kepuasan Kerja dengan Perilaku Kewargaorganisasian (PKO) Guru di SMSK Negeri Kecamatan Pasar Minggu Kota Administrasi Jakarta Selatan. IMPROVEMENT Jurnal Ilmiah Untuk Peningkatan Mutu Manajemen Pendidikan, 3(1), 51. https://doi.org/10.21009/improvement.03106

Organ, D. W., \& Lingl, A. (1995). Personality, satisfaction, and organizational citizenship behavior. Journal of Social Psychology, 135(3), 339-350. https://doi.org/10.1080/00224545.1995.9713963

Organ, D. W., Podsakoff, P. M., \& MacKenzie, S. B. (2006). Organizational citizenship behavior: Its nature, antecedents, and consequences. In Organizational Citizenship Behavior: Its Nature, Antecedents, and Consequences. https://doi.org/10.4135/9781452231082 
ÖZDEM, G. (2012). the Relationship Between the Organizational Citizenship Behaviors and the Organizational and Professional Commitments of Secondary School Teachers. Journal of Global Strategic Management, 2(6), 47-47. https://doi.org/10.20460/jgsm.2012615773

Pandey, S. K., Wright, B. E., \& Moynihan, D. P. (2008). Public Service Motivation and Interpersonal Citizenship Behavior in Public Organizations: Testing a Preliminary Model. International Public Management Journal, 11(1), 89-108. https://doi.org/10.1080/10967490801887947

Rahman, U. (2014). Kepuasan Kerja dan Organizational Citizenship Behavior pada Guru Madrasah Aliyah. Analisa, 21(1), 131. https://doi.org/10.18784/analisa.v21i1.33

Rekhapriyadharshini, A., Jawahar, P. D., \& Ahmed, K. A. A. (2020). Effect of transformational leadership on organizational citizenship behavior: Mediating role of organizational learning culture. LBS Journal of Management \& Research, 18(2), 84-95. https://doi.org/10.5958/0974-1852.2020.00008.5

Robbins, S. P., \& Judge, T. A. (2018). Organizational Behavior, Global Edition (17th Editi). Pearson. https://www.pearson.com/uk/educators/higher-education-educators/program/Robbins-OrganizationalBehavior-Global-Edition-18th-Edition/PGM2152257.html

Rosyati, T., Saprudin, S., \& Alaydrus, A. S. (2020). Kinerja OCB pada guru PAUD ditinjau dari Educational leadership dan Integritas. Jurnal Obsesi: Jurnal Pendidikan Anak Usia Dini, 5(1), 201. https://doi.org/10.31004/obsesi.v5i1.513

Sahrah, A. (2018). Perceived Organizational Support Dan Organizational Citizenship Behavior Pada Perawat Rumah Sakit. Insight: Jurnal Ilmiah Psikologi, 19(1), 40. https://doi.org/10.26486/psikologi.v19i1.598

Somech, A., \& Bogler, R. (2002). Antecedents and Consequences of Teacher Organizational and Professional Commitment. Educational Administration Quarterly, 38(4), 555-577. https://doi.org/10.1177/001316102237672

Sulastri, S., Andriani, C., \& Latifa, S. K. (2018). Pengaruh kompensasi finansial dan kepuasan kerja terhadap organizational citizenship behavior (OCB) pada karyawan PT. Kilang Lima Gunung. Jurnal Kajian Manajemen Bisnis, 7(2), 69-79. https://doi.org/10.24036/jkmb.10882500

Wirawan. (2013). Kepemimpinan:Teori,Psikologi, Perilaku Organisasi,Aplikasi dan Penelitian. Grafndo Persada. 